\title{
USE OF THE 4-STEP METHOD IN PRACTICAL LESSONS ON THE SUBJECT OF ELECTRICAL ENGINEERING AND THE INTRODUCTION OF AN INNOVATIVE DEMO OPTICAL INSTALLATION
}

\author{
Muzaffar Khabibullaevich Murodov \\ Phd, Associate Professor, Uzbekistan \\ Murodjon Yakubdjanovich Nabiev \\ Senior Teacher, Namangan Engineering Construction Institute, Uzbekistan
}

\section{ABSTRACT}

In the process of teaching electrical engineering, visualization plays an important role in the transfer of knowledge about electric current. The main purpose of the lesson is to enrich the imagination, especially in practical exercises, and to put into practice the new knowledge acquired by students in the imagination of the mind. Managing the learning process using the best teaching methods will further improve the quality of education.

KEYWORDS:- Cognitive visualization, visual training, Faraday experience, optical installation, 4-step method, imitation.

\section{INTRODUCTION}

Many methods of imparting new knowledge to students are being developed in modern education. Organizing the lesson in the form of games, puzzles, project methods, etc. But there are sciences in which knowledge cannot be conveyed to the listener's mind without visual aids. For example, in the field of electrical engineering, the use of visual effects, animations, visual aids on topics such as the generation of electric current, the laws of constant and alternating current, transformers, does not achieve the intended purpose of teaching.

According to the research, the principles of teaching based on a modular methodology are revealed. One of them is the principle of cognitive visualization, the essence of which is as follows [1]:

The principle of cognitive visual (observable)this principle is derived from psychologicalpedagogical laws. Exhibitions in teaching increase the productivity of mastery only if they perform the questioning function, as well as the cognitive task. That is why cognitive graphics is a new problematic area of artificial intelligence theory, where complex objects are depicted in the form of computer images. The structural structure of the module is served by colorful cognitive-graphic learning elements. Therefore, images are the main main element of the module. This is:

- develops students' visual and spatial thinking skills; 
CURRENT RESEARCH JOURNAL OF PEDAGOGICS 2(11): 76-82, November

2021 DOI: https://doi.org/10.37547/pedagogics-crjp-02-11-16

ISSN 2767-3278

(C)2021 Master Journals

\section{Crossref doi) 81 Google}

Accepted 25 $5^{\text {th }}$ November, 2021 \& Published 30th November, 2021

- A clear picture of the content of the educational material helps the student to form a systematic knowledge;

- Color pictures increase the effectiveness of receiving and remembering educational material and serve as a means of aesthetic education of students.

Visual information is more important and productive than verbal information. The ability of the visual mechanism to transmit information is much higher than that of hearing. This, in turn, allows the vision system to transmit about 90 percent of the information that a person receives. In addition, visual information is provided at the same time. Therefore, it takes less time to receive and remember information than verbal information. When visual information 27 is used, the impression is on average 5-6 times faster than the verbal statement. A person's trust in visual information is higher than verbal information. However, the yield of reception and memory in visual information does not depend on the length of time between its display. Assimilation of verbal information, on the other hand, depends on it.

A person's trust in visual information is higher than verbal information. It is therefore not in vain that it is said, "It is better to see once than to hear a hundred times."

Another important detail should be noted: the adoption of symbolic-visual information increases the effectiveness of teaching, that is, it is necessary to create conditions for the reproduction of information obtained from educational and scientific literature and computer technology. This indicates the need to individualize teaching.

Below, we consider the coverage of the topic of practice in electrical engineering in a 4-step way, based on the principle of cognitive visualization. Methods of explaining this topic are mainly developed for students of non-energy areas.

The importance of practical training in the transfer of knowledge in the field of electrical engineering. In doing so, the student fills in the gaps that appear in the lecture sessions. Let us use a 4-step method of teaching the law of electromagnetic induction, which came into science under the name of Faraday's experiment in electrical engineering. In doing so, we introduce innovative visual aids developed by the authors [2].

Information about innovative optical display media:

An innovative optical device that is energysaving, low-power, with a power of $15-25 \mathrm{~W}$, and is used by the authors as a non-traditional visual weapon in the educational process compared to the demonstration tools used in the educational process. When using this device, you have the ability to make drawings, graphs, and some moving demonstrations.

4-step method of teaching

As this method emerged in the United States and as conveyor production increased in industrial plants, training methods became necessary so that workers could learn uniformly repetitive hand skills as quickly and perfectly as possible.

The process of acquiring practical skills in this way takes place within 4 steps. The names of these steps are: "Explain", "Show what to do", "Return as shown", "Exercise". That is, the practice teacher first explains to the students a smaller phase of the work, and then shows them what to do. The student must then repeat (imitate) this phase of the work as shown. The student corrects the mistakes of the practice teacher while repeating.

This phase of the work is then repeated many times in the form of an exercise until the student has mastered it perfectly. [3] 


\section{Actions within the 4-step method}

The 4-step method consists of the following. During the implementation of the method, the practice teacher and a student will work:
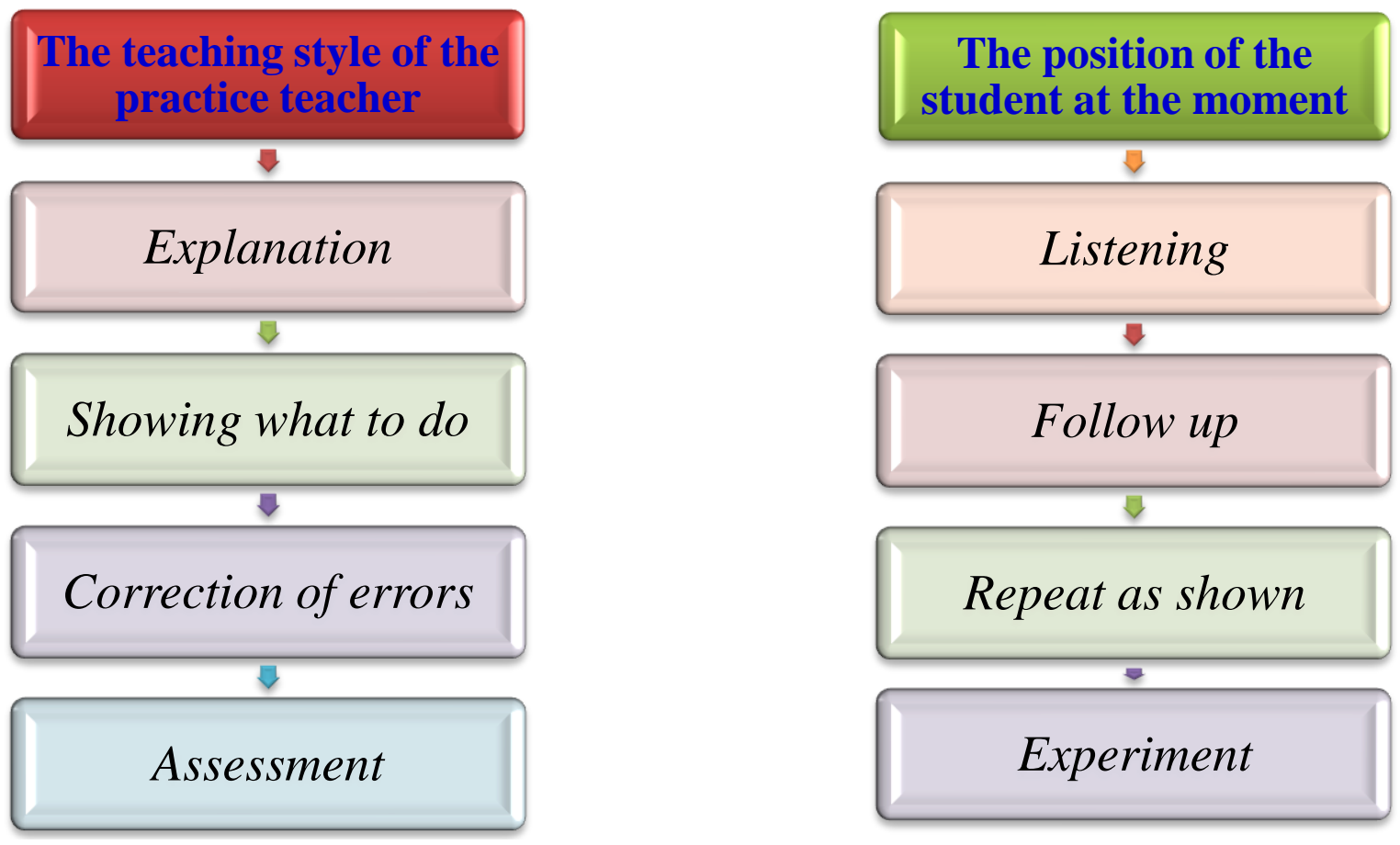

Figure 1. Four-step method block diagram.

Step 1: The practice teacher explains what to do. It gives students all the information they need to apply a particular work phase or a skill. For example, Faraday briefly describes the importance of the experiment, the technology of carrying out the experiment. Students, on the other hand, listen to the oral explanations of the practice teacher.

Step 2: The practice teacher explains how the explained work phase should be done, and the students look on. Thus, the teacher turns to an innovative optical device to explain the phenomenon of electromagnetic induction, which is difficult to imagine, in a simple way. In order for students to be able to imagine how an electric current is generated as a result of an experiment, the parts needed in the drawing are highlighted in separate colors (Figure 2). Usually the practice teacherwill give students comments about what they are doing. That is, the concept of demonstration can also be used here. 
CURRENT RESEARCH JOURNAL OF PEDAGOGICS 2(11): 76-82, November

2021 DOI: https://doi.org/10.37547/pedagogics-crjp-02-11-16

ISSN 2767-3278

(C)2021 Master Journals

crossref do) 88 Google

Accepted 25th November, 2021 \& Published 30 ${ }^{\text {th }}$ November, 2021

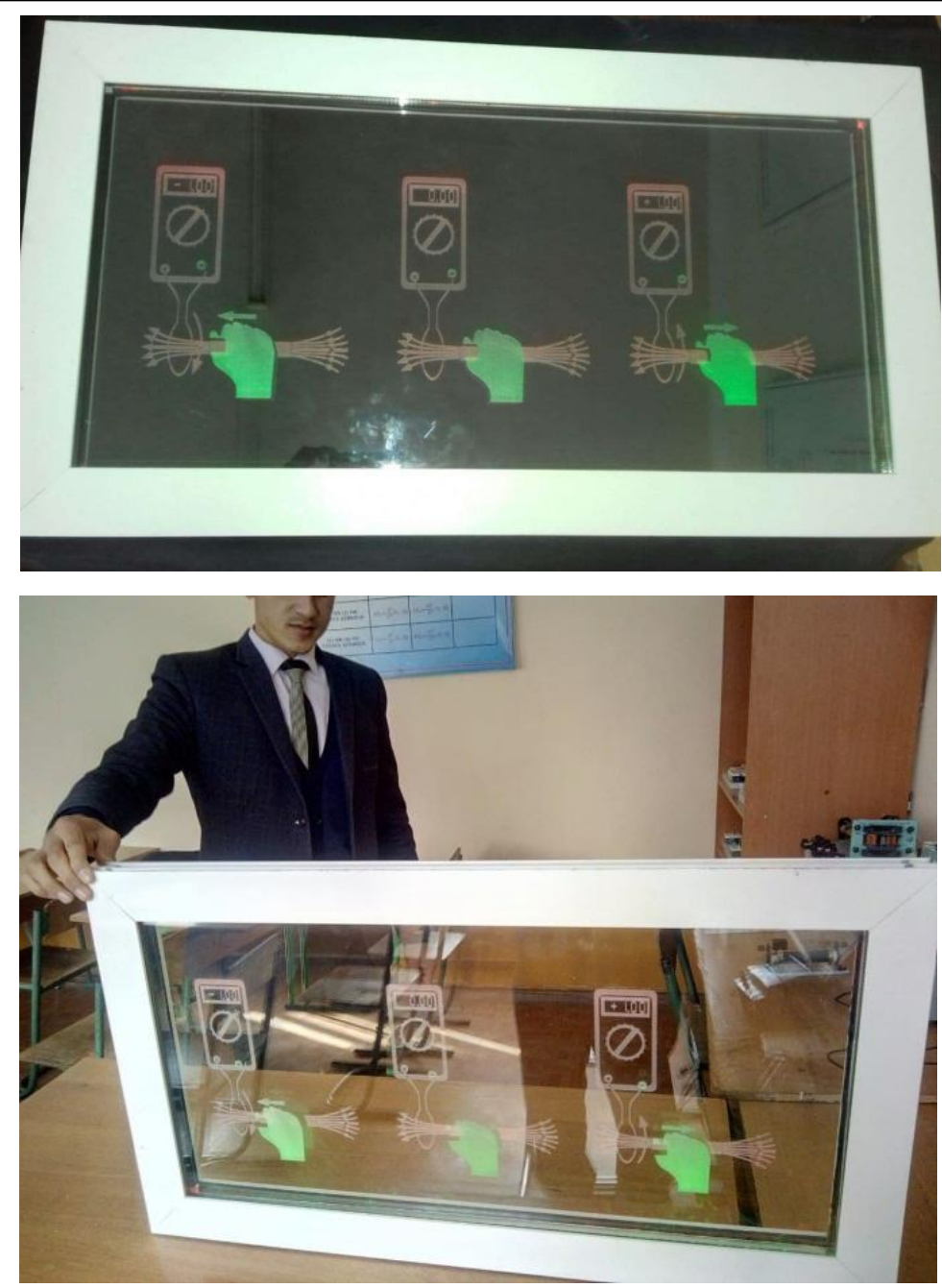

Figure 2. An optical device that demonstrates the Faraday experiment.

Step 3: Return the work phase indicated by the practice teacher as shown. That is, the process demonstrated in the optical device is performed independently by students using the necessary experimental equipment (Figure 3 ). The practice teacher will comment on the work they are doing and correct the mistakes. 



Figure 3. Carrying out experiments using laboratory equipment.

Step 4: Once each student has seen and reviewed the work phase as shown and understood the practice teacher's comments on how to complete the work phase correctly, this work phase is practiced many times and repeated as needed i.e. i.e. until an optimal result is achieved.

Guidelines within the 4-step method.

Step 1:Explanation-motivation (motivation). Providing information. The practice teacher first decides whether to conduct the instruction in the classroom or in the workplace. It depends on the nature and type of instruction. He plans that the instructional time should not exceed 20-30 minutes.

Assignment-oriented work instruction begins with arousing students 'interest because their interest and attention should be focused on what is being studied.

The practice teacher then provides the students with all the information they need to complete the practical assignment and explains the processes to be performed. At the same time, he can use all the teaching and learning materials he knows from his practical experience, such as drawings, work plans, operating instructions, tools and raw materials as visual materials.

The practice teacher explains the work steps in their sequence and, if necessary, requires students to include these steps in their work plans.

At the same time, he can show students examples of good and bad test work in order to demonstrate the difference in quality. students become relatively passive as they listen and watch.

Step 2: Demonstrate what to do - demonstration. At this stage, the practice teacher demonstrates the steps of the work himself / herself. To do this, he must first carefully prepare the required 
CURRENT RESEARCH JOURNAL OF PEDAGOGICS 2(11): 76-82, November

2021 DOI: https://doi.org/10.37547/pedagogics-crjp-02-11-16

ISSN 2767-3278

(C)2021 Master Journals

\section{Crossref doi) 81 Google}

Accepted 25th November, 2021 \& Published 30 ${ }^{\text {th }}$ November, 2021

workplace and hold a demonstration (demonstration) at that workplace. All tools required for the work must be prepared with raw materials and work plan and, if necessary, the appropriate machine (equipment).

During the demonstration, the practice teacher ensures that the students are watching carefully.

It is recommended to demonstrate a skill 3 times:

Demonstration 1: held at normal speed; to give students a full and realistic imagination.

Demonstration 2: deliberately held at a slow speed; to show each stage separately and the features better and to explain the rules of labor safety.

Demonstration 3: held at normal speed; to demonstrate the skill once again in full and to give students an 'inner pace' (i.e. a clear imagination).

During the demonstration, the practice teacher explains each step. Then the direct instruction part ends.

Step 3:Repeat as shown - imitation. Now each of the students must repeat the actions of the practice teacher in the way he or she indicated. As students work, the practice teacher expresses his or her opinion, praises the good work, criticizes the bad work, and demonstrates once again what to do.

Once all students have seen that they understand the work process, the practice teacher signals to start practicing.

Step 4: Experiment. The practice teacher will provide students with enough raw materials to practice the work processes on the instruments and equipment through constant repetition.

Each student works on their own and uses the same processing methods.

If the quality of the work results meets the optimal standard of results (pre-defined quality criteria - specific goals), the work can be completed. The practice teacher acts as a supervisor here [3].

In conclusion, in order to achieve the effectiveness of the lesson, it is necessary to choose the method based on the specifics of the subject. The 4-step teaching method based on the principle of visual-based cognitive visualization has a positive effect on the quality of teaching and learning as a result of students seeing, imagining, remembering and repeating the practical lesson (Faraday's experience) using visual aids.

Samples of experimental optical devices have been developed by the authors and used in practice in educational processes, effective results have been achieved [4]. As a result of practical application of the device, certain achievements can be made in the training of qualified specialists and personnel.

In addition, the proposed optical device can be used purposefully in various sectors of the economy, in the development of entrepreneurship.

\section{REFERENCES}

1. Holliday-Darr K., Blasko D. G., Dwyer C. Improve Cognitive Visualization with a Web Based Interactive Assessment and Training Program //Engineering Design Graphics Journal. - 2009. - T. 64. - №.1

2. Муродов М. Х., Мамаджанов А. Б., Шарипов $\Phi . \quad \Phi . \quad$ Таълимда кўргазмалиликни бойитишда инновацияларни жорий қилиш //Современное образование (Узбекистан). - 2017. - №. 10. 
CURRENT RESEARCH JOURNAL OF PEDAGOGICS 2(11): 76-82, November

2021 DOI: https://doi.org/10.37547/pedagogics-crjp-02-11-16

ISSN 2767-3278

(C)2021 Master Journals

Crossref dof 81 Google

Accepted 25th November, 2021 \& Published 30th November, 2021

3. Pucciarelli F., Kaplan Andreas M. Competition and Strategy in Higher Education: Managing Complexity and Uncertainty, Business Horizons, 2016. Volume 59.

4. Murodov M. K., Sharipov F. P., Matchanova F. K. USE OF INNOVATIVE DEMONSTRATION UNITS ON IMPROVING THE QUALITY OF EDUCATIONAL PROCESSES //Central Asian Problems of Modern Science and Education. - 2019. - T. 4. - №. 2. - C. 763-770. 